\title{
The Rise and Fall of Regulatory Competition in Corporate Insolvency Law in the European Union
}

\author{
Horst Eidenmüller ${ }^{1,2}$
}

Published online: 24 September 2019

(C) The Author(s) 2019

\begin{abstract}
In this article, I discuss the rise and fall of regulatory competition in corporate insolvency law in the European Union. The rise is closely associated with the European Insolvency Regulation (EIR, 2002), and it is well documented. The UK has emerged as the 'market leader', especially for corporate restructurings. The fall is about to happen, triggered by a combination of factors: the recasting of the EIR (2017), the European Restructuring Directive (ERD, 2019) and Brexit (2019). The UK will lose its dominant market position. I present evidence to support this hypothesis.
\end{abstract}

Keywords Insolvency $\cdot$ Bankruptcy $\cdot$ Restructuring $\cdot$ Regulatory competition · Brexit · European directive

\section{Introduction}

Insolvency laws in general and corporate insolvency/restructuring regimes in particular are economically important. Most recently, the Organisation for Economic Co-operation and Development (OECD) has published a study that attempts to link key desirable features of insolvency/restructuring laws with productivity growth in 36 countries. The study finds significant cross-country differences in the extent to which insolvency regimes promote an orderly exit of non-viable firms, indicating that some countries have scope to improve resource allocation and productivity through reforms of insolvency laws and procedures. ${ }^{1}$

The European legal landscape with respect to corporate insolvency/restructuring regimes is characterised by significant diversity. European corporate insolvency law never had its 'Centros moment' following which free choice of the applicable

\footnotetext{
1 OECD (2018).

Horst Eidenmüller

horst.eidenmueller@law.ox.ac.uk

1 Statutory Professor of Commercial Law, University of Oxford, Oxford, UK

2 ECGI Research Associate, European Corporate Governance Institute, Brussels, Belgium
} 
insolvency regime could (suddenly) have become feasible for entrepreneurs and, as a consequence, regulatory competition between the Member States on a significant scale could have ensued. On the contrary: the European lawmaker is involved in a long-haul harmonisation project, attempting to edge out differences between Member States' systems so that local businesses obtain local access to efficient insolvency regimes.

A first important step in this direction was taken in 2002 with the entry into force of the European Insolvency Regulation (EIR). ${ }^{2}$ It was designed to eliminate forum shopping (Recital 4) and to harmonise Member States' jurisdiction and conflicts rules for international insolvencies. However, in practice, it did not achieve this end. Indeed, forum shopping almost became a signature feature of the EIR-both with respect to individual and corporate insolvencies - and the UK emerged as the 'market leader' for corporate restructurings in the European Union (EU).

This article discusses the rise of regulatory competition in corporate insolvency law in the EU, and how the UK came to be the preferred European venue for corporate restructurings. The regulatory landscape for corporate insolvency law in the EU is changing. The EIR was recast in $2017,{ }^{3}$ the EU passed a 'European Restructuring Directive' (ERD) in 2019, ${ }^{4}$ seeking to harmonise Member States' pre-insolvency restructuring regimes, and the UK will probably leave the EU in 2019. This article investigates how these events will affect regulatory competition in corporate insolvency law in the EU. It hypothesises that this competition will be weaker in the future and that the UK will lose its dominant market position. I present evidence to support this hypothesis.

I begin by setting out a simple conceptual framework for assessing regulatory competition in corporate insolvency law in Sect. 2. This is followed by a discussion of the evolution of corporate insolvency law and practice in the EU in Sect. 3 and of regulatory competition under the 'original' EIR in Sect. 4. This discussion is based on known facts. By contrast, in Sects. 5, 6 and 7, I investigate how three key regulatory events - the recasting of the EIR in 2017, the ERD in 2019, and Brexit-are likely to affect regulatory competition and the market for corporate restructurings in the EU. The key claim here is that there will be less regulatory competition and that the UK will almost certainly lose its dominant market position. Recent data on the decline of the popularity of the English Scheme of Arrangement for foreign firms can be interpreted as a first piece of evidence to support this hypothesis. Section 8 concludes.

\footnotetext{
${ }^{2}$ Council Regulation (EC) No. 1346/2000 of 29 May 2000 on insolvency proceedings [2000] OJ L 160/1-18. The EIR entered into force on 31 May 2002.

${ }^{3}$ Regulation (EU) 2015/848 of the European Parliament and of the Council of 20 May 2015 on insolvency proceedings (recast) [2015] OJ L 141/19-72. The recast EIR entered into force on 26 June 2017.

${ }^{4}$ Directive (EU) 2019/1023 of the European Parliament and of the Council of 20 June 2019 on preventive restructuring frameworks [2019] OJ L 172/18-55. The Directive must be transposed by Member States by 17 July 2021 .
} 


\section{Regulatory Competition in Corporate Insolvency Law}

Regulatory competition between states in a particular area of the law presupposes first, a diversity of legal rules that are 'on offer', second, incentives for states to compete with each other, and third, feasibility of choice by market actors. The phenomenon was initially studied with respect to the market for corporate charters in the US where Delaware enjoys a dominant position. ${ }^{5}$ By now, the scholarship on the transnational 'law market' is vast, comprising conceptual, empirical and normative studies relating to many different areas of the law and geographical regions. ${ }^{6}$

One of the key issues in the analysis of regulatory competition is externalities. ${ }^{7}$ One can only hope for an efficient outcome if all-positive and negative-effects of actions by market participants are factored into the decision-making process for a particular legal regime. If affected parties consent to the choice of the applicable law, it may be inferred that this choice is probably beneficial overall.

In the corporate insolvency context, the 'insolvency decision' is usually taken by the debtor's management and/or senior lenders ( 'case placers'). ${ }^{8}$ The key stakeholder group one must be concerned with is outside creditors. There are various ways to get them involved so that credit risk is efficiently priced. If firms were allowed to choose the applicable insolvency regime in their charter/statutes ex ante-this proposal has been discussed in the literature for a long time ${ }^{9}$ - at least contract creditors could be said to have 'consented' to the specified regime. However, so far, jurisdictions worldwide have not allowed such an ex ante choice.

The issue becomes even more problematic if the choice is exercised ex post, i.e., once a corporation already finds itself in financial distress. Two scenarios or versions of insolvency forum shopping must be distinguished. In the first scenario, a firm seeks access to a non-domestic (new) insolvency regime by reincorporating in the target jurisdiction, effectively changing its corporate form, i.e., the corporate laws applicable to it. This is feasible in the EU under the 'Cross-Border Mergers Directive' which has now become part of the 'Company Law Codification Directive' $(\mathrm{CLCD})^{10}$ : a shell corporation is set up in the target jurisdiction, and the distressed firm is then merged with the shell corporation. The Directive contains a number of

\footnotetext{
5 For a recent account see Kahan (2018).

${ }^{6}$ For an overview see Eidenmüller (2011). For a philosophical critique of the 'law market' see Stark (2019).

7 As will become clearer later in the text in Sect. 4, an overall normative assessment of regulatory competition has of course to go beyond externalities. However, potential externalities are a key factor and useful starting point for the analysis.

8 Senior lenders usually bargain for contractual rights to be involved in the 'insolvency decision'. Even if they do not have these rights, they will usually be involved as a source of fresh money to finance the debtor's operations during the insolvency process.

9 Rasmussen (1992); Rasmussen (1997); Eidenmüller (2005).

10 Directive 2005/56/EC of the European Parliament and of the Council of 26 October 2005 on crossborder mergers of limited liability companies [2005] OJ L310/1-9; Directive (EU) 2017/1132 of the European Parliament and of the Council of 14 June 2017 relating to certain aspects of company law (codification) ('CLCD') [2017] OJ L169/46-127.
} 
procedural safeguards to protect creditors' interests before a merger is allowed to go forward. ${ }^{11}$

The second scenario involves a change of a corporation's 'Centre of Main Interests' (COMI) - the key jurisdictional test under the EIR — without a change of the corporate form. From an outside creditor's perspective, such a change is more problematic than a cross-border merger as the procedural safeguards mentioned do not apply to such 'isolated COMI shifts'. However, Member States' courts may scrutinise forum shopping by applying general principles of EU law such as the doctrine of abuse of law, at least in extreme cases. ${ }^{12}$ Under this doctrine, COMI shifts undertaken purely to enrich certain stakeholders at the expense of others could be considered abusive. ${ }^{13}$ As a consequence, the insolvency courts in the target jurisdiction would decline to exercise jurisdiction.

\section{The Evolution of Corporate Insolvency Law and Practice in the EU}

Corporate insolvency practice in the EU has changed significantly in the last two decades. The first change relates to the relevance of corporate restructurings compared to liquidations. Beginning in the 1990s, many European jurisdictions, for the first time, introduced restructuring proceedings for financially distressed corporations. A good example is Germany: it was only with the entering into force of the Insolvenzordnung in 1998 that such a restructuring became possible. ${ }^{14}$ The second change relates to the type of restructuring that market participants seek. Twenty years ago, court-supervised restructurings dominated restructuring practice. However, market participants attempted out-of-court restructurings ('workouts'), where feasible, to save on direct and indirect insolvency costs. A development then came about in many European jurisdictions, establishing pre-insolvency restructuring proceedings with little-if any-interference by courts and/or court-appointed insolvency administrators. ${ }^{15}$ The aim of this new policy was at least threefold: first, to have a statutory framework in place that allows majority decisions to overcome the free-rider problem that destabilises workouts; second, to allow management to continue running the company 'as usual' without being displaced by an outsider trustee or administrator; and third, to do all this before the company becomes insolvent so that the chances of a successful restructuring are higher.

While Member States are experimenting with different corporate insolvency procedures, the European lawmaker is involved in a long-term project that seeks to

\footnotetext{
11 See Arts. 121(2), 123(2)(c) and 124 CLCD.

12 'Abuse of law' is a general principle of EU law. See, for example, CJEU 8 June 2017, Case C-54/16 Vinyls Italia, ECLI:EU:C:2017:433, paras. 51 et seq. with further references.

13 See Eidenmüller (2009). For a 'system approach' to forum shopping and its normative assessment see Block-Lieb (2018).

14 An English translation of the statute is available here: http://www.gesetze-im-internet.de/englisch_ inso/englisch_inso.pdf (last visited on 11 May 2019). The Insolvenzordnung contains a section (\$§ 217 et seq.) which adapts, to a large degree, Chapter 11 of the US Bankruptcy Code.

15 See, for example, Eidenmüller (2017), p 274.
} 
harmonise Member States' laws in the field of corporate insolvency. The rationale put forward by the European Commission to justify this project is to give businesses access to (efficient) local proceedings. This should level out financing costs so that firms compete with their business models instead of benefiting from less-costly insolvency regimes. ${ }^{16}$ It all started with the EIR in 2002 (recast in 2017) which attempted to provide a uniform jurisdictional and private international law framework for cross-border insolvencies in the EU. ${ }^{17}$ The EU did not legislate to harmonise Member States' substantive insolvency regimes until 2019 when it passed the ERD (see Sect. 1 supra). The inroads made by the ERD into Member States' corporate insolvency laws are, however, very limited. The Directive is restricted to pre-insolvency proceedings. Given the widely differing national views and policies on core insolvency matters such as the ranking of claims in an insolvency, it is to be expected that the European harmonisation project will progress only very slowly with respect to these matters.

\section{Regulatory Competition Under the 'Original' European Insolvency Regulation}

As already mentioned in the introduction, the 'original' EIR (2002) attempted to rule out forum shopping and regulatory competition. Recital 4 explicitly stated that ' $\mathrm{i}] \mathrm{t}$ is necessary for the proper functioning of the internal market to avoid incentives for the parties to transfer assets or judicial proceedings from one Member State to another, seeking to obtain a more favourable legal position (forum shopping).' The test for international jurisdiction to administer main insolvency proceedings over the assets of a financially distressed corporation was (and is) a corporation's 'Centre of Main Interests' (COMI). Recital 13 stated that ' $[\mathrm{t}]$ he "centre of main interests" should correspond to the place where the debtor conducts the administration of his interests on a regular basis and is therefore ascertainable by third parties. ${ }^{18}$ The EIR presumes that the COMI corresponds to a corporation's place of registration, but this presumption is rebuttable. Clearly, the COMI test resembles the 'real seat doctrine' as a conflicts rule for corporations. It is still popular in many civil law jurisdictions. ${ }^{19}$ By comparison with the 'incorporation doctrine', which is prevalent in common law jurisdictions, the 'real seat doctrine' is supposed to provide a more stable connecting factor, making forum shopping more difficult.

Despite this explicit policy of reducing or even eliminating forum shopping, such forum shopping started to occur. The main reason for this was (and is) that the COMI test is fact-sensitive and involves a tricky balancing exercise of many relevant

\footnotetext{
16 See COM(2016) 723 final, 22 November 2016, pp 2-4.

17 The EIR flanks the Brussels Ia Regulation on jurisdiction and the recognition and enforcement of judgments in civil and commercial matters which does not apply to insolvency proceedings. The Regulation originally dates from 2002 and was recast in 2015, see [2001] OJ L12/1-23; [2012] OJ L351/1-32.

18 In the recast EIR, this has now been incorporated with minor changes in Art. 3(1).

19 In Germany, for example, the Federal Supreme Court still applies the test to non-EU companies, see Federal Supreme Court, Judgment of 27 October 2008 (Trabrennbahn), II ZR 158/06.
} 
factors such as, for example, the place of executive decision-making and the location of a firm's main creditors and/or assets. This opens up room for strategically motivated manipulations of the relevant criteria. The main forum shoppers were (and are) large corporations: the fixed costs of insolvency forum shopping are high, and these can be more economically incurred by large corporations. ${ }^{20}$ At the same time, the size of the benefits of forum shopping also matters. These are especially high when members of a group of companies simultaneously find themselves in financial distress and need to be restructured. In such a case, the better coordination of multiple proceedings over the assets of many companies translates into significant economic benefits for the group and its creditors.

As already mentioned, insolvency forum shopping may involve a reincorporation and an associated change of the corporate law applicable to the distressed firm (see Sect. 2 supra). Examples of this type of forum shopping are the German firms Schefenacker plc and DNick Holding plc which were reincorporated as English public limited companies before being restructured in the UK. ${ }^{21}$ An example of forum shopping without reincorporation is the restructuring of the PIN group. The holding company, PIN Group S.A., had been incorporated in Luxembourg but filed for bankruptcy in Germany after moving its COMI to Cologne in Germany. ${ }^{22}$

Crucially, forum shopping is neither always good or bad-it can be either, depending on the circumstances of the case. ${ }^{23}$ In the PIN Group case, for example, the change in the holding company's COMI was motivated by a desire to consolidate most of the insolvency proceedings over the group's companies in Colognethereby achieving procedural efficiency gains for the benefit of the group's creditors. By contrast, Hans Brochier Holdings Limited, a Nuremberg-based construction company, filed for bankruptcy in the UK in 2006 despite the fact that its COMI was clearly located in Germany. This attempt to defraud (most of) Brochier's creditors was ultimately defeated. ${ }^{24}$

After the EIR entered into force in 2002, it quickly became clear that, for corporate restructurings, London was the place to go if a distressed company was shopping for a forum different from the courts in the jurisdiction where it had its COMI. The UK offers an established and professional 'restructuring infrastructure' including, in particular, a highly sophisticated and experienced bar and judiciary. It also

\footnotetext{
${ }^{20}$ It is interesting to contrast this with the post-Centros regulatory competition in corporate law. This type of regulatory competition in the EU involves mostly start-ups. The costs of incorporating in a foreign jurisdiction are much smaller than the costs involved in a change of a firm's COMI. On European regulatory competition in corporate law and the reasons why the UK became the 'market leader' for incorporations see Becht et al. (2008).

21 On the Schefenacker restructuring see http://www.allenovery.com/news/en-gb/articles/Pages/Schef enacker-heralds-arrival-of-brave-new-restructuring-world---but-is-Europe-ready-.aspx (last visited on 13 May 2019). On the restructuring of Deutsche Nickel see https://www.quantuma.com/case-studies/deuts che-nickel-eu-coin-group/ (last visited on 13 May 2019).

22 On this case see Amtsgericht (Local Court) Cologne, Resolution of 19 February 2008, 73 IE 1/08.

23 For a detailed discussion, see Eidenmüller (2009).

24 On this case see the reports at https://www.ra-dr-beck.de/presse/presse.php?filter=Hans+Broch ier+Holdings+Limited\&a=unternehmen (last visited on 13 May 2019).
} 
features flexible restructuring tools such as the Scheme of Arrangement which can be used pre- or post-insolvency. ${ }^{25}$

Reliable data on the extent of the UK dominance of the European restructuring market is sparse. However, a 2010 study on cross-border insolvencies in the period from 2002 to 2009, i.e., for the first 7 years into the life of the $\mathrm{EIR}^{26}$ revealed that England quickly and clearly became the 'country of choice' for inbound forum shopping, i.e., for firms that seek to access a restructuring regime in a country other than that in which they are incorporated (Fig. 1).

The OECD study mentioned at the beginning of this article provides some further clues about the potential ${ }^{27}$ reasons for the popularity of English corporate restructuring laws. Building on prior work by Djankov et al., ${ }^{28}$ the OECD has constructed a 'composite indicator of insolvency regimes' that supposedly reflects the degree of ease with which firms can access corporate restructuring proceedings in a particular jurisdiction. It comprises factors such as the right of creditors to initiate the process, the possibility of a stay on creditors' claims and of priority of new financing over unsecured creditors' claims, the possibility of a 'cram-down' on dissenting creditors and the availability of debtor-in-possession (DIP) proceedings. It turns out that Great Britain is the least restrictive (most accessible) jurisdiction when it comes to corporate restructuring proceedings (Fig. 2).

As can probably be expected, the normative assessment of the UK's dominance of the European corporate restructuring market is difficult: Many different factors influence the efficiency calculus, and objective ways of gauging their (quantitative) weight does not exist. We know that easy access to limited liability, discharge and restructuring procedures fosters entrepreneurship. ${ }^{29}$ At the same time, we also know from the OECD study that the UK has quite a lot of 'zombie firms', defined as firms that are older than 10 years and exhibit an interest coverage ratio (EBIT/interest expense) below 1 over three consecutive years (Fig. 3).

This evidence is consistent with data from R3, a trade association for the UK's insolvency, restructuring, advisory and turnaround professionals. According to a study undertaken in 2018, 65\% of the 552 Company Voluntary Arrangements commenced in 2013 were terminated without achieving their intended aims. ${ }^{30}$ Recurring cash-flow problems were cited as the main issue causing this unfortunate result. ${ }^{31}$

\footnotetext{
25 The relevant provisions on the Scheme of Arrangement can be found in Part 26 of the Companies Act 2006, Sections 895 et seq. For a detailed analysis of the Scheme of Arrangement as a restructuring tool, see van Zwieten (2018), pp 575-588.

26 The study by Maria Banda was sponsored by the International Insolvency Institute, see https://www. iiiglobal.org/node/53 (last visited on 13 May 2019). It is on file with the Institute. The graph reproduced in the text is on file with the author.

27 Case placers might of course seek access to English restructuring laws for very different reasons. Neither the OECD nor I have investigated this. At the same time, the reasons set out in the text are at least plausible.

28 Djankov et al. (2008).

29 Armour and Cummings (2008); Braun et al. (2012).

30 See R3 (2018), pp 11-12. For a detailed analysis of the Company Voluntary Arrangement (CVA) as a restructuring tool see van Zwieten (2018), pp 588-611.

31 Van Zwieten (2018).
} 
Whether, overall, increased entrepreneurship as a positive effect outweighs the negative effect of more 'zombie firms' and the opportunity costs associated with these (capital misallocation) must be considered an unresolved issue.

Amongst the various UK restructuring proceedings, the Scheme of Arrangement merits closer analysis. It has become a popular tool to financially restructure English and non-English firms. ${ }^{32}$ As already mentioned, it can be used pre- and post-insolvency. What is even more important, it can, in principle, be accessed without the need for a prior COMI shift and associated costs. Further, court decisions sanctioning a Scheme must be automatically recognised by all EU Member States under the Brussels Ia Regulation, i.e., they have the same 'currency' as domestic court judgments, and there is no need for exequatur proceedings. ${ }^{33}$

Neither the Insolvency Service nor Companies House in the UK hold data on court-sanctioned Schemes of Arrangement. Hence, we constructed a dataset of 190 Scheme cases in the UK in the period from 2012 to 2018 from all cases reported by Westlaw UK. ${ }^{34}$ We differentiated between domestic, EU and non-EU cases. The coding of cases as 'domestic' (UK), 'EU' or 'non-EU' was done on the basis of a company's place of registration. If a company belonged to a group of restructured companies, a case was coded as 'UK' if only UK companies were involved, as 'EU' if another EU jurisdiction was involved, and as 'non-EU' if a company registered in a third country jurisdiction — such as in the US — was involved. Hence, 'non-EU' trumped 'EU' for the purpose of coding.

The data in Fig. 4 clearly shows that the Scheme is a popular restructuring tool. Indeed, the long-term trend is positive. At the same time, the data also reveals that for the subset of EU firms, the curve is bell-shaped-it peaks in 2015/2016, and the Scheme's popularity for EU firms has been in decline since then. Clearly, the overall numbers are quite small and one should not read too much into this data. Nevertheless, it is worth noting the possible trend and to think about what might cause it. 23 June 2016 was, of course, the date of the Brexit vote, and the British pound has lost approximately $10 \%$ against the Euro since then (most of it in the days and weeks immediately following the referendum) - despite the fact that the legal position of the UK as an EU Member State has not yet changed. I will come back to Brexit and how it might have already affected or (will) affect the market for corporate restructurings in the EU in Sect. 7.

The analysis of regulatory competition under the 'original' EIR in the previous section has demonstrated two things: first, despite it being the explicit policy of the Regulation to rule out insolvency forum shopping, it has become a characteristic feature of the corporate restructuring practice in the EU and, as a consequence, regulatory competition in European corporate insolvency law is now a well-established phenomenon. It comprises both restructuring regimes that are within the scope of the EIR and regimes, such as the English Scheme of Arrangement, that are not

\footnotetext{
32 See Payne (2013).

33 See Eidenmüller and Frobenius (2011).

${ }^{34} \mathrm{I}$ am indebted to Amit Zac for constructing the dataset.
} 


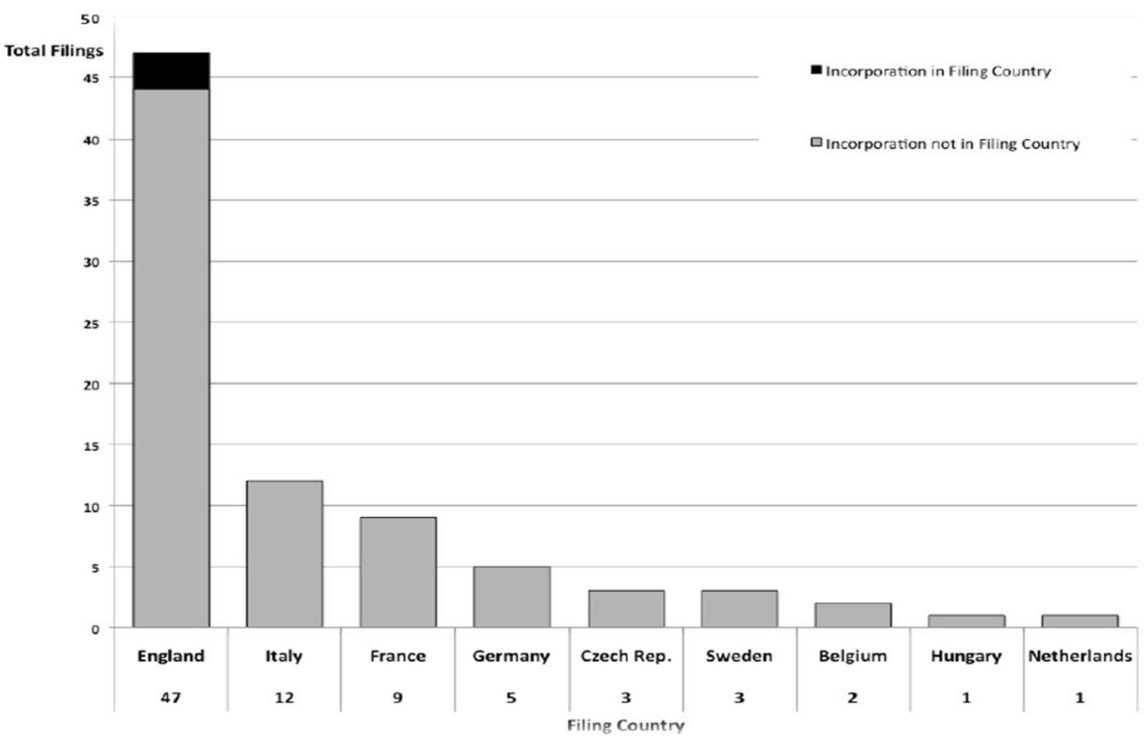

Fig. 1 Cross-border insolvencies in the EU, by filing country and by incorporation (2002-2009). Source: Maria Banda (2010)

\section{Scale of 0 to 1 from least to most stringent}

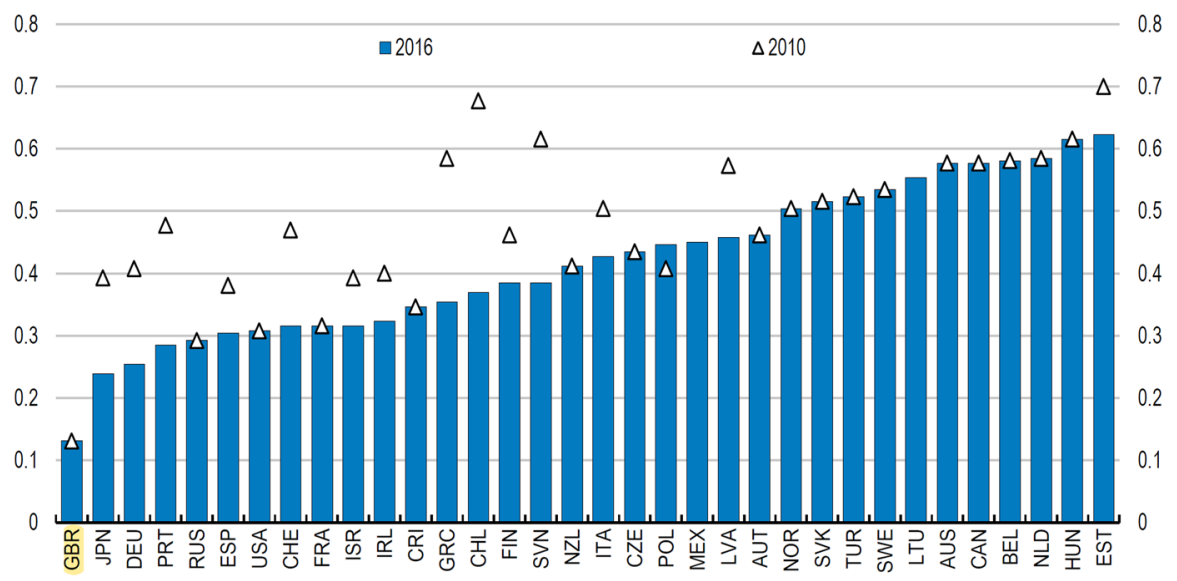

Fig. 2 Composite indicator of insolvency regimes. Source: OECD (2018), p 103

within the scope of the Regulation. Second, the UK has emerged as the clear market leader for corporate restructurings in the EU.

While the European regulatory landscape for corporate restructurings has been stable since the entry into force of the 'original' EIR in 2002 until 2016, a series of regulatory events since 2016 might cause significant changes in the market for European corporate restructurings: the recasting of the EIR in 2017, the ERD in 2019 and, as 


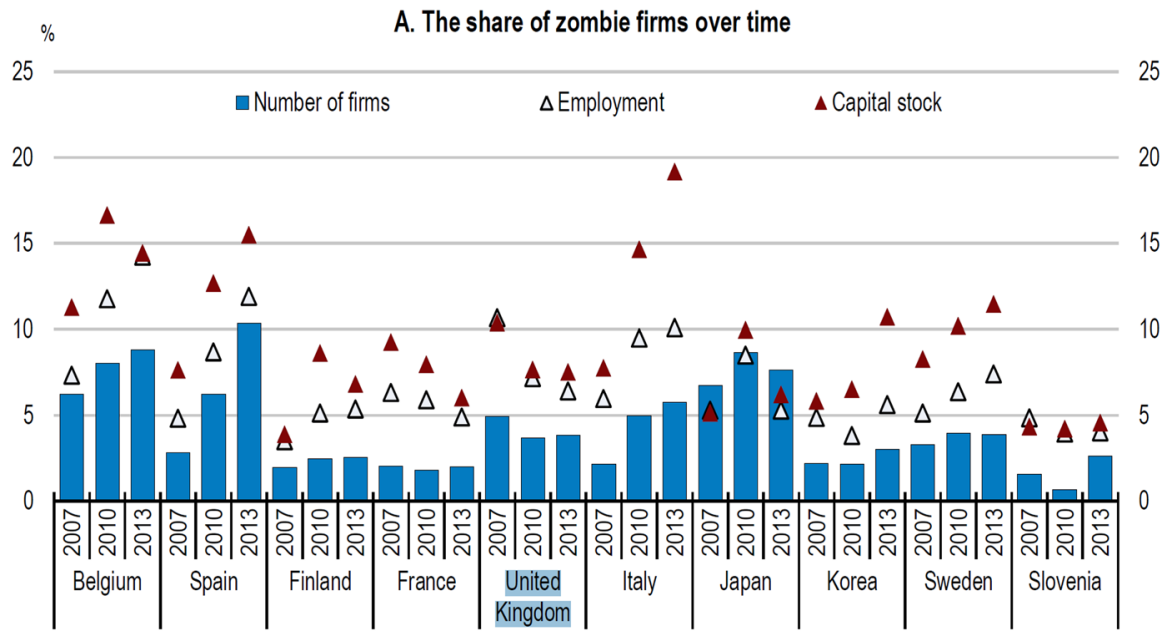

Fig. 3 The share of zombie firms over time. Source: OECD (2018), p. 90 (The tables and data are taken from McGowan et al. (2017), p 11)

\section{Scheme of Arrangements}

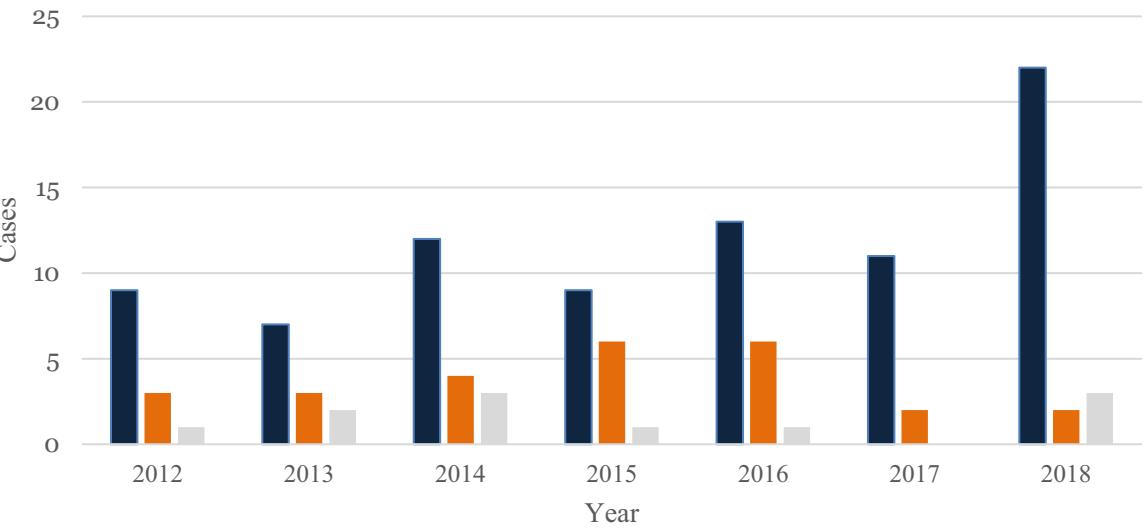

- Total Number of Cases $\quad$ EU $\quad$ Non-EU

Fig. 4 Scheme of arrangements. Source: Amit Zac, Westlaw UK search (2019)

already mentioned, Brexit, which is also due to happen in 2019. I will examine these regulatory events in turn. Whereas the analysis so far was based largely on known facts, the following analysis will involve mostly hypotheses which can and should be tested once sufficient data is available. 


\section{The Recast European Insolvency Regulation (2017)}

The recasting of the EIR in 2017 was the long-term consequence of a review process which was mandated by Article 46 of the 'original' EIR. According to this provision, '[...] the Commission shall present to the European Parliament, the Council and the Economic and Social Committee a report on the application of this Regulation. The report shall be accompanied if need be by a proposal for adaptation of this Regulation.' The reform discussion centred around three issues: the scope of the Regulation, the treatment of groups of companies, and forum shopping. ${ }^{35}$

The scope of the 'original' EIR was restricted to '[...] collective insolvency proceedings which entail the partial or total divestment of a debtor and the appointment of a liquidator' (Article 1(1)). Following the development of the restructuring practice discussed in Sect. 3 supra, the European lawmaker broadened the scope of the Regulation. It now encompasses proceedings that are initiated pre-insolvency and that do not necessarily affect all creditors of a debtor company, ${ }^{36}$ and it also encompasses proceedings during which the debtor 'stays in possession', i.e., no insolvency administrator is appointed ('DIP proceedings'). Interestingly, the Scheme of Arrangement is not within the scope of the recast EIR. ${ }^{37}$ This is for political reasons only: the UK was interested in continuing to 'supply' the Scheme to foreign companies without these companies having to move their COMI to the UK, i.e., without being forced to incur significant transaction costs. The other Member States were apparently happy with this situation.

The second important structural change to the EIR relates to the treatment of members of groups of companies who simultaneously find themselves in financial distress. As was already mentioned (see Sect. 4 supra), forum shopping in such a setting is often motivated by the desire to bring all proceedings in one jurisdiction and to achieve some procedural coordination and associated efficiency gains. The recast EIR attempts to address this issue by a lengthy new section (Chapter V) on 'Insolvency Proceedings of Members of a Group of Companies' (Articles 56-77). The new provisions are not very useful: the coordination mechanism is bureaucratic, and it will be cumbersome to use it. To the best of my knowledge, the new tool has yet to be applied in a cross-border restructuring case.

Finally, the recast EIR acknowledges that forum shopping need not always be harmful. It can be beneficial in the sense that it is done to increase the net assets available for distribution amongst a distressed firm's creditors. Hence, the European lawmaker has introduced new rules designed to prevent only abusive forum

\footnotetext{
35 For a discussion of various reform proposals, see Eidenmüller (2013). For an analysis of the main structural changes introduced by the recast EIR, see van Zwieten (2016).

${ }^{36}$ From a policy perspective, the inclusion of not fully collective proceedings within the scope of the recast EIR is problematic: it forces Member States to automatically recognise decisions in such proceedings (Arts. 19, 32) - like enforceable domestic judgments - despite the fact that the debtor company may not be insolvent and the proceeding does not attempt to solve a common pool problem, see Eidenmüller (2018a).

37 See Recital 16 of the Regulation and Annex A (the Scheme of Arrangement is not listed in Annex A, and such listing is decisive with respect to the Regulation's scope, see Art. 1(1) last sentence).
} 
shopping (see Recital 29). The 'original' EIR had established a rebuttable presumption that a company's COMI is in the place of its registered office. According to the recast EIR, the registered office of a company is presumed to be the COMI only ' $[\ldots]$ if [it] has not been moved to another Member State within the 3-month period prior to the request for the opening of insolvency proceedings' (Article 3(1)). Further, '[a] court seized of a request to open insolvency proceedings shall of its own motion examine whether it has jurisdiction pursuant to Article 3' (Article 4(1) [emphasis added]—-see also Recitals 27 et seq.).

Taken together, these provisions aim to make sure that a firm's COMI is 'taken seriously' by Member States' insolvency courts. That neither rules out COMI changes nor makes such changes more burdensome. It does not even hinder abusive COMI shifts. The only effect of the provisions is that Member States' courts look more closely at where the COMI (now) really is, and that they must do so especially if the COMI has been shifted on the eve of an insolvency filing.

I hypothesise that the overall effect of the recast EIR on forum shopping and regulatory competition in corporate insolvency law in Europe will be minimal. The recast EIR does bring pre-insolvency restructurings within the scope of the Regulation so that these must now automatically be recognised everywhere in the EU. However, the dominant competitor in the pre-insolvency restructuring market is the UK, and the recast EIR does not change the cross-border legal regime applicable to Schemes of Arrangement. The new group coordination procedure aims to reduce the incentive to forum shop in cases of group restructurings. However, the new procedure is much too cumbersome to be useful. Finally, the new provisions on jurisdiction might make forum shopping on the eve of an insolvency filing a little bit more difficult by watering down the relevance of the registered office as a presumption of a firm's COMI. At the same time, COMI shifts are possible even on the eve of insolvency, and benevolent forum shopping is not discouraged.

\section{The European Restructuring Directive (2019)}

The European Restructuring Directive was long in the making. It all started with a Recommendation of the European Commission in 2014, calling upon the Member States to modernise their national restructuring laws. ${ }^{38}$ The Member States were unimpressed, so the Commission followed up with a proposal for a European Restructuring Directive in $2016 .{ }^{39}$ The guiding idea was to give small and mediumsized enterprises (SMEs) local access to pre-insolvency restructurings. As already discussed, forum shopping is relatively (and much) more expensive for SMEs than for large firms (see Sect. 4 supra).

\footnotetext{
38 Commission Recommendation 2014/135/EU of 12 March 2014 on a new approach to business failure and insolvency. On the Recommendation see, for example, Eidenmüller and van Zwieten (2015).

39 Proposal for a Directive of the European Parliament and of the Council on preventive restructuring frameworks, second chance and measures to increase the efficiency of restructuring, insolvency and discharge procedures and amending Directive 2012/30/EU, COM(2016) 723 final of 22 November 2016.
} 
There was much to criticise about the Commission's proposal ${ }^{40}$ : it was flawed because it would have created a refuge for failing firms that should be liquidated; flawed because it ruled out going-concern sales for viable firms and because it was, in essence, a twisted and truncated insolvency proceeding-it looked like a Chapter 11 proceeding but without strong court involvement from the beginning and without the tools needed for the court to guarantee a fair outcome of the process.

It would have been good if the European Commission had withdrawn its proposal. Instead, European firms should have been given the option to choose a 'European Insolvency Regime' in their charter/statutes. ${ }^{41}$ This regime could be embodied in a 'fully specified' (complete) European Regulation, guaranteeing legal certainty to stakeholders. Firms could be given the additional option to have this regime enforced by a specialised European insolvency court. Firms would not be required to opt into the European regime and could stick to their domestic insolvency regimes. Hence, horizontal regulatory competition between the Member States for the best 'insolvency product' would be preserved, and a new, vertical regulatory competition between the Member States and the EU would be introduced in the field of insolvency law.

Unfortunately, the European Commission pressed on with its project, ${ }^{42}$ and in June 2019, the ERD became law. ${ }^{43}$ Member States now have two years to implement the provisions of the Directive into their national legal systems. During the law-making process, a few deficits of the original proposal were remedied. Going concern sales are now possible according to Article 2(1(2)) of the Directive. Other severe problems remain. The framework established by the ERD still creates a refuge for failing firms. The idea that a complicated plan confirmation process including 'cross-class cram-downs' (Articles 8 et seq.) could be suitable for restructuring SMEs is far-fetched. A process that aims to achieve this must be simple and quick, and a bargaining process amongst stakeholder classes-which includes shareholders (Article 12)—coupled with a complicated voting and confirmation system is just the opposite.

What is more, the legislative process has given interest groups ample opportunities to lobby for changes to the Commission's proposal that have made an inefficient 'legal product' even worse. For example, according to Article 5(3), Member States must now '[...] require the appointment of a practitioner to assist the debtor and creditors in negotiating and drafting the [restructuring] plan [...]' under certain circumstances. This means that a pre-insolvency restructuring under the Directive cannot be run as a DIP proceeding if a stay is granted and the appointment of such a practitioner is deemed necessary by the competent judicial or administrative authority or a cross-class cram-down is part of the plan confirmation process. This requirement restricts contractual freedom, reduces flexibility and makes the restructuring process more complicated and costly. Engaging advisors or experts should

\footnotetext{
40 See Eidenmüller (2017).

41 Eidenmüller (2017).

42 The Commission's work appears to have been assisted by a report from Stanghellini et al. (2018).

43 See n. 4 supra.
} 
have been left to the participating stakeholders as it is in a Chapter 11 or a Scheme of Arrangement process.

Another 'political price' the European law-maker had to pay for getting the ERD adopted is a serious compromise to the harmonisation goal that was driving the project from the beginning. The Directive contains more than 70 regulatory options for the Member States. ${ }^{44}$ So what we can expect is that Member States will use the remaining freedom they have to 'experiment away' from the inefficient proceeding forced upon them by the European law-maker. Also, the institutional environment-courts, insolvency professionals, etc.-is absolutely crucial for the proper functioning of insolvency or restructuring processes, ${ }^{45}$ and this environment differs significantly amongst the Member States. Incentives to forum shop will, therefore, continue to exist even after Member States have implemented the ERD.

At the same time, it is clear that the ERD will bring about some harmonisation. It will, to a non-trivial degree, reduce Member States' room to experiment with innovative and potentially radical new types of restructuring procedures. The ERD is a Procrustean bed that rules out radical innovations with respect to corporate restructuring regimes. In the future, for example, efficient regimes will not only be digital ones-these regimes will probably also, to a significant degree, be automated and assisted by artificial intelligence. This is impossible with the ERD as the relevant governing platform.

As a consequence, the ERD will reduce forum shopping and regulatory competition with respect to corporate restructurings in the European Union. Were the UK to stay in the EU, it would force the 'market leader' to change its flagship product, the Scheme of Arrangement, at least to a certain degree-reducing the pressure on the other Member States to modernise their regimes and make them more efficient. Unfortunately, the negative effects on the market for corporate restructurings might be even more profound-because of Brexit.

\section{Brexit (2019)}

As things stand as I write this (in July 2019), the UK is set to leave the EU on 1 November 2019. ${ }^{46}$ Indeed, Boris Johnson, the new Prime Minister and leader of the Conservative Party, has announced that ' $[\mathrm{w}] \mathrm{e}$ will leave the EU on 31 October, deal or no deal. ${ }^{47}$ As with almost everything about Brexit, this is subject to change at short notice. At the same time, it now seems highly likely that Brexit will (eventually) happen.

\footnotetext{
44 See Freitag (2019), p 542.

45 See Eidenmüller (2017), p 291.

46 See European Council Decision taken in agreement with the United Kingdom extending the period under Article 50(3)TEU, 11 April 2019, https://data.consilium.europa.eu/doc/document/XT-20013-2019INIT/en/pdf (last visited on 30 May 2019).

47 See https://www.politicshome.com/news/uk/political-parties/conservative-party/boris-johnson/news/104,142/ boris-johnson-says-brexit (last visited on 26 May 2019).
} 
The key question for the purposes of this article then becomes: how will this affect the framework conditions for the market for corporate restructurings and regulatory competition in corporate insolvency law in Europe? The answer to this question is much clearer than the question of Brexit itself. As I have analysed elsewhere in detail, ${ }^{48}$ after a possible transition period of a couple of years to a possible agreement on the future relationship between the EU and the UK, there is nothing in the documents discussed so far to suggest that the EIR/Brussels Ia Regulation would be replaced by a bilateral arrangement with similar effect. ${ }^{49}$ Given its position as a highly popular venue for corporate restructurings/litigations in the EU, the UK clearly does have an interest in such an alternative regime. However, the other Member States do not share this interest.

The consequences of this are straightforward: restructuring decisions by English courts will no longer benefit from automatic recognition under the EIR/Brussels Ia Regulation. Courts of EU Member States will decide autonomously, based on their respective national civil procedure rules for cross-border cases, whether or not to recognise English court decisions. This applies also to those EU Member States which have adopted the UNCITRAL Model Law on Cross-Border Insolvency Law: the Model Law does not foresee automatic recognition. Rather, recognition is the consequence of a decision which may or may not be granted on an application to the competent court, depending on whether certain requirements have been fulfilled (or not). ${ }^{50}$

The only exception to this might come in the form of the Hague Convention on Choice of Court Agreements. ${ }^{51}$ It was signed on 30 June 2005 and is in force with respect to the EU Member States since 1 October 2015. The UK's accession to the Convention is currently suspended up and until after Brexit becomes effective, i.e. until 1 November 2019. ${ }^{52}$ However, the scope of the Convention is very limited. It does not cover insolvency proceedings (Article 2(2)e), and it requires an '[...] exclusive choice of court agreement[s] concluded in civil or commercial matters' (Article 1(1)). Hence, the Convention would apply to Schemes of Arrangement in international cases only if they are restricted to debt instruments with exclusive choice of court agreements, and if Schemes are not considered to be insolvency proceedings

\footnotetext{
48 Eidenmüller (2018b), pp 880 et seq.

49 In the absence of an agreed Brexit deal and a transition period, this will be the legal position immediately once Brexit becomes effective.

50 See Arts. 15 et seq. of the Model Law, http://www.uncitral.org/pdf/english/texts/insolven/1997-Model -Law-Insol-2013-Guide-Enactment-e.pdf (last visited on 26 May 2019). I have argued elsewhere that Schemes of Arrangement do not qualify as 'insolvency proceedings' within the meaning of the Model Law, see Eidenmüller (2018a), pp 70-71. This is consistent with the treatment of Schemes under the recast EIR and a decision of the German Federal Supreme Court (Bundesgerichtshof), Case No. IV ZR 194/09 (Equitable Life), Judgment of 15 February 2012, para. 39. However, US courts take a different view. See Eidenmüller (2018a), p 65 with references to the case law.

51 For the text of the Convention, see https://assets.hcch.net/docs/510bc238-7318-47ed-9ed5-e0972 510d98b.pdf (last visited on 27 May 2019).

52 See

https://www.hcch.net/en/instruments/conventions/status-table/notificati ons/?csid=1318\&disp=resdn (last visited on 27 May 2019).
} 
within the meaning of the Convention. ${ }^{53}$ This would conform to their treatment under the EIR but contradict the case law of US courts in applying the Model Law. ${ }^{54}$

To illustrate how this new legal framework for corporate restructurings might play out vis-à-vis an EU Member State, take the case of Germany. According to the case law of the CJEU, Member States must apply the EIR to determine international jurisdiction for insolvency proceedings falling within the scope of the EIR also vis$\grave{a}$-vis third countries, such as the (post-Brexit) UK. ${ }^{55}$ So German courts will look to a company's COMI to determine whether they_or the courts of another state-have international jurisdiction to open (main) insolvency proceedings. When it comes to recognising UK insolvency proceedings, German courts will apply Section 343(1) of the German Insolvency Code ('Insolvenzordnung'). It stipulates that ' $\mathrm{t}] \mathrm{he}$ opening of foreign insolvency proceedings shall be recognised. This shall not apply (1) if the courtsfregime in their charter/statutes of the state of the opening of proceedings do not have jurisdiction in accordance with German law; (2) where recognition leads to a result which is manifestly incompatible with major principles of German law, in particular where it is incompatible with basic rights. ${ }^{56}$ So UK insolvency proceedings may or may not be recognised by German courts. ${ }^{57}$

The same applies to English court decisions sanctioning a Scheme of Arrangement unless a Scheme is restricted to debt instruments with exclusive choice of court agreements and is not considered to be an insolvency proceeding so that it would fall within the scope of the Hague Convention (see supra). German courts will apply Section 328(1) of the German Code of Civil Procedure ('Zivilprozessordnung'). According to this provision, '[r]ecognition of a judgment handed down by a foreign court shall be ruled out if: (1) The courts of the state to which the foreign court belongs do not have jurisdiction according to German law; [...] (4) The recognition of the judgment would lead to a result that is obviously incompatible with essential principles of German law, and in particular if the recognition is not compatible with fundamental rights; (5) Reciprocity has not been granted.' ${ }^{58}$ Again, a judgment sanctioning a Scheme may or may not be recognised by German courts.

I hypothesise that this will profoundly affect the market for corporate restructurings and regulatory competition in corporate insolvency law in the EU. The unique feature that has helped the UK assume its current leadership position will disappear-as discussed, English court decisions on corporate restructurings will no longer have to be recognised automatically by the remaining EU Member States.

\footnotetext{
53 On this question see, for example, Matthews and Oehm (2016).

54 See n. 51 supra.

55 CJEU 16 January 2014, Case C-328/12 Ralph Schmidt, ECLI:EU:C:2014:6, paras. 20-39.

56 For an English language version of the 'Insolvenzordnung' see http://www.gesetze-im-internet.de/ englisch_inso/englisch_inso.html\#p1404 (last visited on 26 May 2019).

57 Pursuant to para. 111(1A)(b), Schedule B1 and Section 1 Insolvency Act 1986, the English courts would have administration or CVA jurisdiction (as applicable) over an EEA incorporated company regardless of whether its COMI is in the UK. Assuming jurisdiction with respect to companies which have their COMI outside the UK would almost certainly lead German courts to refuse to recognise UK court judgments in restructuring cases.

58 For an English language version of the 'Zivilprozessordnung' see https://www.gesetze-im-internet.de/ englisch_zpo/englisch_zpo.html (last visited on 26 May 2019).
} 
Significant legal uncertainty will influence considerations about possible forum shopping into the UK, and significant legal uncertainty is what the players in this market do not want. Hence, it is highly likely that Brexit will eliminate the dominant competitor jurisdiction in the European restructuring market. ${ }^{59}$ The UK 'restructuring industry' will likely take a big hit.

Other (remaining) Member States will probably seek to catch some of the UK's market share. Jurisdictions like Ireland may have a competitive edge in the restructuring market because English is the lingua franca of international commerce and Ireland has a similar common law system. Hence, some of the 'Scheme business' might move to Ireland ('offensive regulatory competition'). ${ }^{60}$ But other jurisdictions are gearing up, too. The Netherlands has recently (on 1 January 2019) created an English-language commercial court to resolve international business disputes: 'Proceedings are in English. Judgments are in English. The NCC [Netherlands Commercial Court] has the tools to communicate effectively and provide swift and firm guidance in complex litigation. ${ }^{61}$ Similar projects are being initiated in Germany. ${ }^{62}$ The effect of these dynamics will probably not so much lie in another European jurisdiction taking the place of the UK as the European 'restructuring capital'. We do not see an uptick in Irish Scheme cases that could or would make up for the decline in the popularity of the UK Scheme of Arrangement. Rather, these dynamics will primarily reduce the incentive to forum shop to the UK in cross-border cases and get a domestic restructuring instead ('defensive regulatory competition').

Legally speaking, this all depends on the UK, in fact, exiting the EU-with the associated changes in the applicable framework for cross-border restructurings already described. At the same time, it is not unlikely that the observable drop in the popularity of the English Scheme of Arrangement after 2016 can already be attributed to anticipated (and discounted) future changes. After all, the whole Brexit process is fraught with political and legal uncertainties, and this may also tip the balance on the margin against forum shopping to the UK already now.

\section{Conclusion}

In this article, I have discussed the rise and fall of regulatory competition in corporate insolvency law in the European Union. I have also attempted to discuss fundamental conceptual issues relating to a normative assessment of the 'market for corporate restructurings'. The story of the rise of regulatory competition in the European corporate restructuring market and of the UK's position as a 'market leader' is based on facts. The fall of regulatory competition and of the UK losing its dominant

\footnotetext{
${ }^{59}$ See Eidenmüller (2018b), pp 886-887. Cross-border international restructurings will be inhibited further by the fact that cross-border mergers under Title II Chapter II CLCD (see supra n. 10) involving UK limited companies will be impossible in the future, see Eidenmüller ibid.; Schmidt (2019), pp 1099-1101.

${ }^{60}$ On Irish Scheme procedures see, for example, McCann FitzGerald (2019).

${ }^{61} \mathrm{https} / / /$ www.rechtspraak.nl/English/NCC/Pages/default.aspx (last visited on 26 May 2019).

${ }^{62}$ See Wagner (2017); Rühl (2018), pp 1075-1076.
} 
position is my prediction, based on a combination of factors: the recasting of the EIR (2017), the European Restructuring Directive (2019) and, especially, Brexit (2019). I present evidence to support this hypothesis. The English Scheme of Arrangement has been losing its appeal as a restructuring tool in cross-border settings since 2016. The main findings of this article can be summarised as follows:

1. The key issue with respect to regulatory competition in corporate insolvency law is containing possible externalities of choice by the dominant market actors ('case placers').

2. The emphasis in European corporate insolvency law practice today is on preinsolvency/'debtor in possession' (DIP) restructurings. The applicable European corporate insolvency law framework is currently still characterised by significant legal diversity.

3. The 'original' European Insolvency Regulation (EIR, 2002) attempted to rule out forum shopping. It did not achieve this aim. On the contrary: forum shopping became a signature feature under the EIR, and the UK became the 'market leader' jurisdiction with respect to European corporate restructurings. The available data clearly confirms this assessment. The popularity of the UK as a restructuring venue also stems from the attractiveness of the Scheme of Arrangement-a procedure that is not within the scope of the EIR.

4. The European market for corporate restructurings will be affected by three regulatory events that have taken place since 2017 or are about to take place: the recasting of the EIR in 2017, the European Restructuring Directive (ERD) in 2019 and Brexit in 2019. I formulate the following three hypotheses:

a. The recast EIR (2017) will not (significantly) affect forum shopping and regulatory competition in corporate restructurings.

b. The ERD (2019) will (significantly) reduce forum shopping and regulatory competition in corporate restructurings. It must be implemented by the Member States by 2021 .

c. Brexit (2019) will eliminate the dominant competitor in the European restructuring market, i.e., the UK. This might already explain the decline of the popularity of the Scheme of Arrangement in cross-border cases from 2016 onwards. I present some evidence in the form of hand-collected data on cross-border Schemes of Arrangement to support this hypothesis.

Regulatory competition in European corporate law happened by design: the CJEU handed down its famous Centros judgment, a controversial interpretation of the freedom of establishment guaranteed by the TFEU (Treaty on the Functioning of the European Union), and European entrepreneurs immediately seized upon the newly acquired freedom to make use of company law forms available in other Member States to pursue their business objectives. By contrast, regulatory competition in European corporate insolvency law happened by accident: it was the unwelcome consequence of the entering into force of the EIR in 2002.

The European law-maker still struggles to find a consistent approach to the fundamental issue of harmonisation versus regulatory competition-in corporate 
(insolvency) law as elsewhere. In corporate insolvency law, for example, the recast EIR now explicitly acknowledges that forum shopping and the associated regulatory competition may be a good thing. At the same time, the European lawmaker is now harmonising Member States' pre-insolvency restructuring frameworks, edging out differences and reducing the incentive to forum shop and the associated regulatory competition. This is unfortunate. The ERD is an inefficient and harmful piece of legislation-it should be repealed.

However, the real nail in the coffin for regulatory competition in corporate insolvency law in the EU will probably come with Brexit. It will eliminate the dominant competitor and standard setter in the European restructuring market. There is not much the EU can do about this. Brexit is an act of harm inflicted by the UK upon itself.

Acknowledgements I should like to thank the participants in the 3rd Annual Conference of the Oxford Business Law Blog on 'Centros and European Company Law: Twenty Years of Living Dangerously' on 15 March 2019 for helpful suggestions. Special thanks for perceptive comments go to Sarah Paterson, Luca Enriques, Conor McLaughlin and Tilmann Frobenius. I should also like to thank Amit Zac for excellent research assistance.

Open Access This article is distributed under the terms of the Creative Commons Attribution 4.0 International License (http://creativecommons.org/licenses/by/4.0/), which permits unrestricted use, distribution, and reproduction in any medium, provided you give appropriate credit to the original author(s) and the source, provide a link to the Creative Commons license, and indicate if changes were made.

\section{References}

Armour J, Cumming D (2008) Bankruptcy law and entrepreneurship. Am Law Econ Rev 10:303-350

Becht M, Mayer C, Wagner HF (2008) Where do firms incorporate? Deregulation and the cost of entry. J Corp Finance 14:241-256

Block-Lieb S (2018) Reaching to restructure across borders (without over-reaching), even after Brexit. Am Bankruptcy Law J 92:1-52

Braun R, Eidenmüller H, Engert A, Hornuf L (2012) Does charter competition foster entrepreneurship? A difference-in-difference approach to European company law reforms. J Common Mark Stud 51:399-415

Djankov S, Hart O, McLiesh C, Shleifer A (2008) Debt enforcement around the world. J Polit Econ 116:1105-1150

Eidenmüller H (2005) Free choice in international company insolvency law in Europe. EBOR 6:423-447

Eidenmüller H (2009) Abuse of law in the context of European insolvency law. Eur Co Financ Law Rev 6:1-28

Eidenmüller H (2011) The transnational law market, regulatory competition, and transnational corporations. Ind J Glob Legal Stud 18:707-749

Eidenmüller H (2013) A new framework for business restructuring in Europe: the EU Commission's Proposals for a reform of the European Insolvency Regulation and beyond. Maastricht $\mathrm{J}$ Eur Comp Law 20:133-150

Eidenmüller H (2017) Contracting for a European insolvency regime. EBOR 18:273-304

Eidenmüller H (2018a) What is an insolvency proceeding? Am Bankruptcy Law J 92:53-71

Eidenmüller H (2018b) Collateral damage: Brexit's negative effects on regulatory competition and legal innovation in private law. Zeitschrift für Europäisches Privatrecht 26:868-891

Eidenmüller H, Frobenius T (2011) Die internationale Reichweite eines englischen Scheme of Arrangement. Wertpapier-Mitteilungen 65:1210-1219 
Eidenmüller H, van Zwieten K (2015) Restructuring the European business enterprise: the European Commission's Recommendation on a new approach to business failure and insolvency. Eur Bus Organ Law Rev 16:625-667

FitzGerald M (2019) Brexit: a unique Irish opportunity for cross-border restructuring? https://www. mccannfitzgerald.com/uploads/Brexit_a_Unique_Opportunity_for_Cross-Border_Restructuring. pdf. Accessed 14 June 2019

Freitag R (2019) Grundfragen der Richtlinie über präventive Restrukturierungsrahmen und ihrer Umsetzung in das deutsche Recht. Zeitschrift für Wirtschaftsrecht 40:541-552

Kahan M (2018) The state of state competition for incorporations. In: Gordon JN, Ringe W-G (eds) The Oxford handbook of corporate law and governance. OUP, Oxford, pp 105-128

Matthews R, Oehm M (2016) The Hague Convention on Choice of Court Agreements: an unexpected game changer for English schemes of arrangement? Butterworths J Int Bank Financ Law 31:641-644

McGowan MA, Andrews D, Millot V (2017) Insolvency regimes, zombie firms and capital reallocation. OECD Economics Department Working Papers No 1399. http://www.oecd.org/officialdocuments/ publicdisplaydocumentpdf/?cote=ECO/WKP(2017)31\&docLanguage=En. Accessed 30 May 2019

OECD (2018) Policies for productivity: the design of insolvency regimes across countries. http://www. oecd.org/eco/growth/policies-for-productivity-the-design-of-insolvency-regimes-across-countries2018-going-for-growth.pdf. Accessed 6 May 2019

Payne J (2013) Cross-border schemes of arrangement and forum shopping. EBOR 14:563-589

R3 (Association of Business Recovery Professionals) (2018) Company voluntary arrangements: evaluating success and failure. https://www.r3.org.uk/media/documents/policy/policy_papers/corporate_ insolvency/R3_ICAEW_CVA_Report_May_2018.pdf. Accessed 16 May 2018

Rasmussen R (1992) Debtor's choice: a menu approach to corporate bankruptcy. Tex Law Rev 71:51-121

Rasmussen R (1997) A new approach to transnational insolvencies. Mich J Int Law 19:1-36

Rühl G (2018) Auf dem Weg zu einem europäischen Handelsgericht? Juristenzeitung 73:1073-1082

Schmidt J (2019) Auswirkungen des Brexit im Bereich des Gesellschaftsrechts. Zeitschrift für Wirtschaftsrecht 40:1093-1101

Stanghellini L, Mokal R, Paulus Ch, Tirado I (eds) (2018) Best practices in European restructuring: contractualised distress resolution in the shadow of the law. Wolters Kluwer and CEDAM, Milan

Stark J (2019) Law for sale: a philosophical critique of regulatory competition. OUP, Oxford

Van Zwieten K (2016) An introduction to the European insolvency regulation, as made and as recast. In: Bork R, van Zwieten K (eds) Commentary on the European insolvency regulation. OUP, Oxford, pp $1-38$

Van Zwieten K (2018) Goode on principles of corporate insolvency law, 5th edn. Sweet \& Maxwell, London

Wagner G (2017) Rechtsstandort Deutschland im Wettbewerb: Impulse für Justiz und Schiedsgerichtsbarkeit. Beck, Munich

Publisher's Note Springer Nature remains neutral with regard to jurisdictional claims in published maps and institutional affiliations. 